\title{
Editorial
}

\section{CAN MEDICAL MUSHROOMS FIGHT AGAINST SARS-CoV-2/COVID-19?}

\author{
Abdul Kader Mohiuddin ${ }^{1 *}$ \\ Author information: ${ }^{1}$ Secretary \& Treasurer, Dr. M. Nasirullah Memorial Trust \\ Received: 03-06-2021; Accepted: 03-08-2021; Published: 03-09-2021.
}

The power of mushrooms as medicine was recognized nearly two thousand years ago. They are nature's miniature pharmaceutical factories, rich in a vast array of novel constituents and wide open for exploration.

Reishi mushroom, also called "the mushroom of immortality", yields miraculous health benefits and contains over 400 bioactive compounds, which have a number of medicinal effects. More than 150 novel enzymes have been identified from mushroom species so far $[1,2]$.

Medicinal Basidiomycetes mushrooms (including reishi mushroom, almond mushroom, pom-pom mushroom, and maitake mushroom) are usually consumed in China, Japan, Thailand, and Korea as immune response modifiers for prevention of cancer, or as nutritional support during chemotherapy, and for chronic inflammatory conditions such as hepatitis and other diseases.

According to the Scandinavian Journal of Immunology, medicinal Basidiomycetes mushrooms would have merit as prophylactic or therapeutic add-on remedies in COVID19 infection, as well as for the immune overreaction and damaging inflammation that occurs with COVID-19 attack [3].

A Thailand-based research group, supported by Chulalongkorn University of Bangkok, recently revealed six low-toxic/non-toxic compounds in mushrooms having SARS-CoV-2 protease inhibitory activity [4].

\footnotetext{
Corresponding Author: Abdul Kader Mohiuddin

Secretary \& Treasurer, Dr. M. Nasirullah Memorial Trust

E-mail: dr.m.nasirullah.trust@gmail.com, Contact: +8801789914496

Orcid Id: https://orcid.org/0000-0003-1596-9757

Web of Science Researcher ID: T-5428-2019
}

Chaga mushrooms (grows mainly on the bark of birch trees in Northern Europe, Siberia, Russia, Korea, Northern Canada, and Alaska) possess a powerful enzymatic system and a strong system of defense due to their parasitic mode of life. They have shown promising results in attenuation of inflammatory responses that have been associated with COVID-19-as reviewed by a research team from the University of Bradford, UK [5].

Beta-glucans are sugars that are found in the cell walls of certain saprophytes, lichens, and plants, most commonly used for heart disease and high cholesterol. $\beta$-glucans from the edible shiitake mushroom show a protective response to a wide range of viral infections and may potentially reduce key cytokines involved in cytokine storm experienced in severe cases of COVID-19 [6].

Recent studies show that selenium and zinc play particular roles in cardiovascular conditions, suggesting their beneficial roles against COVID-19. When biofortified, dried fruiting bodies of reishi mushroom may serve as a nutritional source of these essential elements [7-10].

Presently medicinal mushrooms are mainly used as dietary supplements or functional food. Special precautions should be there, like cooking procedure, amount to consume, source of collection, and most importantly, hypersensitivity (allergy) of an individual person before consumption. Nevertheless, they have the potential to become real drugs from medicinal plants. Also, to explore them as dietary supplement, preclinical and clinical trials and legal authorization are necessary.

\section{REFERENCES:}

1. Cör D, Knez Ž, Knez Hrnčič M. Antitumour, Antimicrobial, Antioxidant and Antiacetylcholinesterase Effect of Ganoderma Lucidum Terpenoids and Polysaccharides: A Review. Molecules. 2018;23(3):649. Published 2018 Mar 13. doi:10.3390/molecules23030649 
2. Stamets P, Zwickey H. Medicinal Mushrooms: Ancient Remedies Meet Modern Science. Integr Med (Encinitas). 2014;13(1):46-47.

3. Hetland G, Johnson E, Bernardshaw SV, Grinde B. Can medicinal mushrooms have prophylactic or therapeutic effect against COVID-19 and its pneumonic superinfection and complicating inflammation?. Scand J Immunol. 2021;93(1):e12937. doi:10.1111/sji.12937

4. Rangsinth P, Sillapachaiyaporn C, Nilkhet S, Tencomnao $T$, Ung AT, Chuchawankul S. Mushroom-derived bioactive compounds potentially serve as the inhibitors of SARS-CoV-2 main protease: An in silico approach. Journal of Traditional and Complementary Medicine. 2021;11(2):158-172. doi:10.1016/j.jtcme.2020.12.002

5. Shahzad F, Anderson D, Najafzadeh M. The Antiviral, Anti-Inflammatory Effects of Natural Medicinal Herbs and Mushrooms and SARS-CoV-2 Infection. Nutrients. 2020;12(9):2573. Published 2020 Aug 25. doi:10.3390/nu12092573

6. Murphy EJ, Masterson C, Rezoagli E, et al. $\beta$-Glucan extracts from the same edible shiitake mushroom Lentinus edodes produce differential in-vitro immunomodulatory and pulmonary cytoprotective effects - Implications for coronavirus disease (COVID-19) immunotherapies. Sci Total Environ. 2020;732:139330. doi:10.1016/j.scitotenv.2020.139330
7. Jayawardena R, Sooriyaarachchi $P$, Chourdakis $M$, Jeewandara $C$, Ranasinghe $P$. Enhancing immunity in viral infections, with special emphasis on COVID-19: A review. Diabetes Metab Syndr. 2020;14(4):367-382. doi:10.1016/j.dsx.2020.04.015

8. Thota SM, Balan V, Sivaramakrishnan V. Natural products as home-based prophylactic and symptom management agents in the setting of COVID-19. Phytother Res. 2020;34(12):3148-3167. doi:10.1002/ptr.6794

9. Rahman MM, Mosaddik A, Alam AK. Traditional foods with their constituents antiviral and immune system modulating properties. Heliyon. 2021;7(1). doi:10.1016/j.heliyon.2021.e05957

10. Yanuck SF, Pizzorno J, Messier H, Fitzgerald KN. Evidence Supporting a Phased Immuno-physiological Approach to COVID-19 From Prevention Through Recovery. Integr Med (Encinitas). 2020;19(Suppl 1):835. 